\title{
REVIEW: PENGEMBANGAN BATIK MOTIF KHAS DAERAH \\ DI BALAI BESAR KERAJINAN DAN BATIK
}

\author{
Review: Development Of Regional Specialty of Batik Motifs \\ At Center For Handicraft And Batik
}

Irfa'ina Rohana Salma

Balai Besar Kerajinan dan Batik, Jl. Kusumanegara No.7, Semaki, Umbulharjo, Kota Yogyakarta, Daerah Istimewa Yogyakarta 55166

\author{
Korenspondesi Penulis \\ Email : irfasalma@gmail.com
}

\author{
Naskah Masuk : 10 Februari 2019 \\ Revisi : 09 Maret 2019 \\ Disetujui : 29 Mei 2019
}

Kata kunci: pengembangan, batik motif khas daerah, Balai Besar Kerajinan dan Batik

Keywords: development, typical regional batik motifs, Center for Handicrafts and Batik

\begin{abstract}
ABSTRAK
Balai Besar Kerajinan dan Batik (BBKB) adalah lembaga pemerintah dibawah Kementerian Perindustrian yang mempunyai tugas melaksanakan kegiatan litbang kompetensi industri kerajinan dan batik, kerjasama, standardisasi, pengujian, sertifikasi, dan kalibrasi. Pengembangan motif batik khas daerah merupakan salah satu kegiatan dari pengejawantahan tugas sebagai lembaga litbang industri kerajinan dan batik. Kegiatan ini dilaksanakan agar setiap daerah memiliki batik dengan ciri khas dan keunikan tersendiri yang berbeda dengan corak batik daerah lain. Tujuan tulisan ini adalah untuk mengumpulkan data kegiatan pengembangan desain motif batik khas daerah yang telah dilakukan BBKB. Metode yang digunakan adalah kualitatif dengan mendapatkan data dari literatur jurnal, buku, katalog, dan internet. Pengembangan motif telah dilaksanakan sejak tahun 1970-an. Model pengembangan yang dilakukan yaitu melalui program kerja Penelitian dan Pengembangan (litbang), penerbitan buku dan katalog, pelatihan batik daerah, lomba desain motif batik, dan kreativitas mandiri pegawainya. Program yang paling efektif adalah pengembangan motif yang langsung dipraktikkan dalam suatu pelatihan batik daerah. Pengembangan desain motif khas daerah telah menghasilkan batik yang memiliki ciri khas kedaerahan yang semakin menambah khasanah kekayaan corak batik Indonesia.
\end{abstract}

\section{ABSTRACT}

The Center for Handicraft and Batik (called BBKB) is a government agency under the Ministry of Industry which has the task of conducting out research and development of the handicraft and batik industry competencies, cooperation, standardization, testing, certification, and calibration. The development of regional specialty of batik motifs is one of the activities duty embodied as a research and development institution for the handicraft and batik industry. This activity is conductedso that each region has its own characteristics and uniqueness batik motifs different from other regional batik motifs. The purpose of this paper is to find out the activities that have been carried out by BBKB in developing batik industry, especially in regional specialty batik motifs. The qualitative method is used by getting data from the literature of journals, books, catalogs, and the internet. The result was that batik motifs has 
developed since at the 1970s. The development model carried out are through annual office $R \& D$ working programs, book or catalog publishing, regional batik training, batik motif design competitions, and independent supporting employees creativities. This activities have produced batik cloth that has regional specialty characteristics adding the treasure of Indonesia's batik.

\section{PENDAHULUAN}

Dewasa ini, ketika berkunjung ke berbagai wilayah di Indonesia akan dijumpai motif-motif batik khas daerah, padahal daerah tersebut tidak dikenal sebagai basis tradisi industri batik. Penumbuhan dan pengembangan industri batik memang telah diupayakan oleh pemerintah, bahkan ketika pemerintahan Hindia Belanda yaitu tahun 1922 dengan mendirikan lembaga "Textile Inrichting En Batik Proefstation". Lembaga ini kemudian lebih dikenal dengan nama "Balai Batik". Pada era kemerdekaan lembaga ini bernama Balai Penelitian Batik, karena tuntutan ruang lingkup yang lebih luas maka dikembangkan menjadi Balai Penelitian Batik dan Kerajinan. Tahun 1980 Balai Penelitian Batik dan Kerajinan berubah menjadi Balai Besar Penelitian dan Pengembangan Industri Kerajinan dan Batik. Tahun 2002 lembaga ini berganti nama lagi menjadi Balai Besar Kerajinan dan Batik (Sejarah BBKB, 2018). Balai Besar Kerajinan dan Batik (BBKB) merupakan salah satu Unit Pelayanan Teknis, Kementerian Perindustrian RI yang berada di Yogyakarta. Adapun tugasnya sesuai dengan Permenperin Nomor: 46/MIND/PER/6/2006 yaitu : melaksanakan kegiatan penelitian, pengembangan, kerjasama, standardisasi, pengujian, sertifikasi, kalibrasi dan pengembangan kompetensi industri kerajinan dan batik sesuai kebijakan teknis yang ditetapkan oleh Kepala Badan Penelitian dan Pengembangan Industri. BBKB beralamat di Jalan Kusumanegara No. 7 Kota Yogyakarta.
Penumbuhan dan pengembangan industri batik yang dilakukan BBKB bekerjasama dengan dinas daerah yang terkait serta didukung oleh para pemangku kepentingan senantiasa berupaya meningkatkan kemajuan industri kecil menengah (IKM) batik. Batik adalah kain bermotif indah yang dibuat secara spesifik yaitu dengan penggunaan lilin batik sebagai bahan perintang dalam proses pewarnaannya (Salma, I. R., Wibowo, A. A., \& Satria, 2015). Lilin batik yang merintangi resapan warna dalam pencelupan, maka terjadilah motif di kain. Salah satu aspek penting dalam produk batik adalah desain motif hiasnya (Sartika, Eskak, \& Sunarya, 2017). Pengertian batik tersebut sudah sesuai dengan SNI 0239:2014 tentang Batik - Pengertian dan Istilah, yaitu batik adalah kerajinan tangan sebagai hasil pewarnaan secara perintangan menggunakan malam (lilin batik) panas sebagai perintang warna dengan alat utama pelekat lilin batik berupa canting tulis dan atau canting cap untuk membentuk motif tertentu yang memiliki makna. Batik tulis adalah batik yang dibuat dengan menggunakan alat utama canting tulis sebagai alat melekatkan malam (BSN, 2014).

Motif hias pada batik berdasarkan proses penciptaannya ada ada tiga yaitu motif klasik, motif pengembangan, dan motif modern. Motif klasik adalah motifmotif tradisional yang telah mencapai puncak estetikanya yang biasanya merupakan batik kraton. Motif pengembangan merupakan motif kreasi baru yang diciptakan untuk tujuan 
penganekaragaman motif menyesuaikan kebutuhan dan perkembangan zaman. Motif ini diciptakan masih mengacu pada motif-motif yang telah ada sebagai referensi penciptaannya. Motif modern adalah motif kreasi baru yang lebih bebas, tidak terikat pada kaidah-kaidah motif tradisi, tetapi sebaiknya masih ada nilai visual dan rasa sebagai karya batik (Eskak, 2018). Pengembangan motif dilakukan sebagai upaya diversifikasi desain motif yang bertujuan menciptakan motif khas batik suatu daerah yang unik, menarik, dan berdaya jual. Motif batik hasil pengembangan memiliki daya tarik karena diciptakan dengan inspirasi dari keunikan alam dan budaya daerah. Pengembangan adalah suatu tindakan kreatif untuk meningkatkan atau menghasilkan kebaruan dengan berpijak dari hal-hal terdahulu yang relevan dan selaras. Aspek penting pengembangan adalah kebaruan desain motif, karena kebaruan menjadi salah satu daya tarik konsumen dalam membeli suatu produk (Sartika, Eskak, \& Sunarya, 2017).

Motif khas daerah yaitu motif batik yang memiliki unsur-unsur rupa yang unik dan karakteristik sehingga mencirikan daerah tertentu. Motif khas daerah dikreasikan dengan cara menggali potensi alam dan budaya daerah yang unik dan menonjol serta sudah dikenal luas oleh masyarakat. Kekayaan alam dan budaya daerah dapat dijadikan inspirasi berkarya seni yang bernilai ekonomi sebagai sarana memajukan kesejahteraan masyarakat di era industri kreatif dewasa ini (Yoga \& Eskak, 2015).

Pengembangan industri batik gencar dilakukan karena mempunyai prospek ekonomi sebagai industri kreatif yang dapat menyerap banyak tenaga kerja. Batik mempunyai prospek pasar luas karena merupakan industri penghasil kain bermotif indah yang mempunyai fungsi sebagai bahan sandang dan interior yang dibutuhkan masyarakat (Salma, Eskak, \& Wibowo, 2016). Batik bermotif khas daerah juga dapat menjadi souvenir yang diminati karena berciri khas suatu daerah, memberi kenangan, mudah dilipat dan dibawa, serta mempunyai kegunaan praktis.

Uraian di atas menunjukkan bahwa pengembangan batik motif khas daerah dapat memajukan industri batik karena menghasilkan motif khas yang mampu meningkatkan daya saing IKM batik daerah. Tujuan penulisan ini adalah untuk mengumpulkan data kegiatan pengembangan desain motif batik khas daerah yang telah dilakukan BBKB. Data tersebut kemudian direview hasil dan kemanfaatannya untuk pengembangan industri batik pada masa kini dan masa depan.

\section{METODOLOGI PENELITIAN}

Metode yang digunakan adalah diskriptif kualitatif dengan mendapatkan data dari literatur jurnal, buku, katalog, internet, dan wawancara informan ahli. Metode deskriptif kualitatif digunakan untuk menggambarkan pengembangan motif khas daerah oleh BBKB dengan sistematis, faktual, dan akurat. Deskriptif adalah gambaran secermat mungkin mengenai suatu hal atau objek penelitian. Menurut Nazir (2013) metode deskriptif adalah studi untuk menemukan fakta dengan interpretasi yang tepat. Data dianalisis secara kualitatif dengan interpretatif yaitu dengan melalui beberapa proses seperti: verifikasi data, reduksi data, penyajian data, dan penarikan kesimpulan (Moleong, 2012).

\section{HASIL DAN PEMBAHASAN}

Hasil

Kegiatan pengembangan desain motif batik dilakukan BBKB untuk mendukung 
IKM batik daerah yang umumnya masih tertinggal pada masalah kreativitas dalam pengembangan motif baru khas daerah. Kreativitas baik sebagai bentuk pengembangan maupun penciptaan orisinal merupakan salah satu bentuk usaha untuk memajukan industri batik. Desain motif batik khas daerah yang indah dan disukai konsumen, akan mampu menggerakkan produksi lebih dinamis serta menjadikan usaha lebih maju sehingga menjadi bisnis yang menguntungkan. Model pengembangan batik motif khas daerah yang dilakukan BBKB yaitu; Program kerja litbang tahunan, Penerbitan buku atau katalog, Pelatihan batik daerah, Lomba desain motif batik, dan Kreativitas mandiri pegawai. Model-model penegembangan tersebut akan dijelaskan secara lebih terperinci dalam bagian pembahasan berikut ini.

\section{Pembahasan}

Model pengembangan batik motif khas daerah yang telah dilakukan BBKB telah menghasilkan batik yang memiliki ciri khas kedaerahan yang semakin menambah khasanah kekayaan corak batik Indonesia. Penjelasannya secara runtut dipaparkan di bawah ini.

\section{Program Litbang Desain Motif}

Kegiatan litbang desain batik motif khas daerah yang dipublikasikan di jurnal ilmiah terbitan BBKB yaitu Dinamika Kerajinan dan Batik (DKB) didapatkan data tertua dilakukan tahun 1995 dan ditulis di jurnal tahun 1996. Namun pakar batik akademis periode awal yang mendedikasikan kepakarannya di BBKB yaitu S.K. Sewan Susanto (2018) dalam bukunya Seni Kerajinan Batik Indonesia menyebutkan bahwa pengembangan motif baru sudah dilakukan sejak tahun 1967, dan pada tahun 1970 baru mulai disukai masyarakat. Namun kegiatan selanjutnya dan hasil karya motif batiknya tidak tercatat dalam publikasi sehingga sulit ditelusuri.

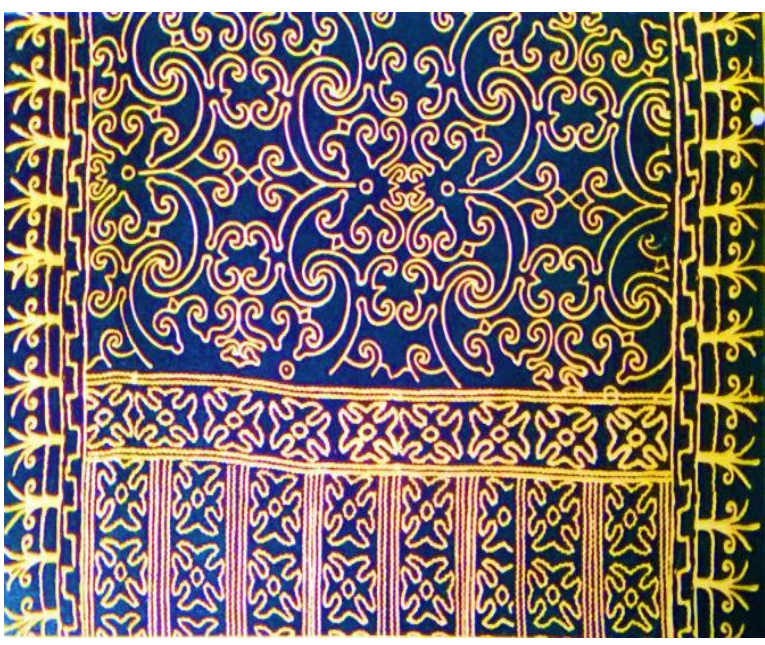

Gambar 1. Motif Gumin Tambun khas Kalimantan Tengah (Riyanto, Pamungkas, \& Ja'far, 1997)

Penelusuran data di laman http://ejournal.kemenperin.go.id/dkb telah didapatkan beberapa arsip tulisan mengenai pengembangan motif batik. Arsip yang tertua adalah tulisan dengan judul Penerapan Ragam Hias Kalimantan Tengah Untuk Motif Batik tahun 1996. Pengembangan dilakukan dengan menerapkan motif tradisional baik dari ukiran kayu, anyaman, maupun tenun kemudian disesuaikan untuk dekorasi pada kain dengan teknik batik. Hasilnya ada 15 motif batik khas daerah Kalimantan Tengah yang berhasil dikreasikan yaitu; Garing Ngaderang, Gumin Tambun, Kambang Munduk, Batang Pantar, Batang Garing Belum, Lawang Suri, Kala Bambang Kurai, Tatu Payung, Pating Muang, Muang Sulah Bintang, Bintik Amban Balanga, Garing Ngader, Rempah Gurantung, Bajakah Munduk, Bambang Kumpang (Ja'far \& Riyanto, 1996). Salah satu hasil motifnya 
yaitu Gumin Tambun dapat dilihat pada Gambar 1.

Motif batik khas Sumatera Utara juga menjadi perhatian pengembangannya oleh BBKB dalam kegiatan litbang tahun 2003. Kegiatan yang kemudian ditulis dalam Jurnal DKB dengan judul Pemanfaatan Ragam Hias Etnik Sumatera Utara Untuk Pengembangan Motif Batik. Kegiatan ini menghasilkan 12 motif batik yaitu; Pintu Perik, Tiang Pengadilan, Topeng Simalungun I, Topeng Simalungun II, Gajah Dompak Depan, Gajan Dompak Samping, Patung Primitif Nias, Ukiran Bunga, Babi, Pahatan Batu Nias, Daun, dan Cicak/Borospati (Suhartini, Haryanto, \& Wijanarko, 2004).

Dasawarsa belakangan ini BBKB mulai menyadari arti pentingnya pengembangan desain motif yaitu bahwa produk batik tidak hanya berkualitas secara fisik saja, tetapi juga berkualitas secara estetik. Tahun 2013 ditemukan tulisan berjudul Rekayasa Pengembangan Desain Motif Batik Khas Melayu, pengembangan motif dilakukan dengan mengkreasikan kembali unsurunsur seni etnis Melayu menjadi motif batik khas Melayu. Kegiatan ini menghasilkan 10 motif yaitu; Ayam Berlaga, Bungo Matahari, Kuntum Bersanding, Lancang Kuning, Encong Kerinci, Durian Pecah, Bungo Bintang, Bungo Pauh Kecil, Riang-Riang, Bungo Nagaro (Murwati \& Masiswo, 2013). Daerah Maluku juga mendapat perhatian pengembangan motif batiknya oleh BBKB. Pengembangan motif dilakukan dengan mengambil sumber inspirasi dari ornamen ukiran tradisional Maluku. Kegiatan yang kemudian dipublikasikan dengan judul Aplikasi Ornamen Khas Maluku Untuk Pengembangan Desain Motif Batik ini, menghasilkan 3 motif yaitu: Siwa, Siwa Talang, dan Matahari Siwa Talang (Masiswo \& Atika, 2014).

Motif batik yang berkembang di Bali juga mendapat perhatian BBKB, batik Bali dinilai kurang mencerminkan identitas khas daerah, oleh karena itu perlu diciptakan motif batik yang berciri khas Bali. Sumber inspirasi penciptaan motifnya digali dari budaya dan alam Bali. Kegiatan ini kemudian dipublikasikan dengan judul Pengembangan Motif Batik Khas Bali. Kreativitas ini menghasilkan 5 motif batik yang mempunyai karakteristik khas Bali, yaitu; Jepun Alit, Jepun Ageng, Sekar Jagad Bali, Teratai Banji dan Poleng Biru (Salma, Masiswo, Satria, \& Wibowo, 2015). Batik Jember juga mendapatkan perhatian BBKB, batik Jember selama ini identik dengan motif daun tembakau, namun visualisasinya dalam motif batik kurang berkarakter karena motif yang muncul adalah seperti gambar daun pada umumnya. Oleh karena itu BBKB melakukan penciptaan motif khas Jember yang sumber inspirasinya digali dari hal yang lebih karakteristik agar ciri khas Jember lebih terlihat. Kegiatan ini kemudian dipublikasikan dengan judul Kopi dan Kakao Dalam Kreasi Motif Batik Khas Jember. Kegiatan ini berhasil menciptakan 6 motif yaitu; Uwoh Kopi, Godong Kopi, Ceplok Kakao, Kakao Raja, Kakao Biru, dan Wiji (Salma, Wibowo, \& Satria, 2015).

Pengembangan motif batik khas daerah juga dilakukan di Kupang, Nusa Tenggara Timur. BBKB melakukan 
pengembangan motifnya dengan mengambil sumber inspirasi dari motifmotif tradisional tenun khas daerah setempat. Kegiatan yang dipublikasikan dalam tulisan berjudul Kreasi Batik Kupang ini menghasilkan 6 motif yaitu; Rukun Kupang, Teguh Bersatu, Pucuk Mekar, Liris Kupang, Kuda Sepasang dan Kuda Kupang (Salma, Eskak, \& Wibowo, 2016).

Perkembangan industri batik di Papua mengalami berbagai kendala, antara lain stagnasi pembuatan motif yang hanya berorientasi pada maskot daerah yaitu burung cendrawasih. Oleh karena itu perlu dilakukan diversifikasi desain dengan mengambil ide alternatif dari budaya masyarakat Papua. Kemudian BBKB melakukan pengembangan desain motif dengan sumber inspirasi dari piranti tradisi masyarakat Papua. Piranti tradisi yaitu alatalat tradisional yang biasa digunakan oleh masyarakat Papua ketika di rumah, saat bekerja, berperang, dan berkesenian. Kegiatan yang dipublikasikan dalam tulisan berjudul Piranti Tradisi Dalam Kreasi Batik Papua ini menghasilkan 6 motif yaitu; Honai Besar, Honai Kecil, Tifa Besar, Tifa Kecil, Tambal Ukir Besar dan Tambal Ukir Kecil. (Salma, Ristiani, \& Wibowo, 2017).

Pada tahun 2017 BBKB melakukan pengembangan produk dengan mengombinasikan antara teknik tenun dan teknik batik yang kemudian menghasilkan produk baru dengan akronim "nuntik" yaitu perpaduan antara tenun dan batik. Produk yang dihasilkan sangat unik dan khas. Tematik motif nuntik yang diangkat yaitu seni budaya Nusa Tenggara Timur. Kegiatan ini dipublikasikan dalam tulisan berjudul
Diversifikasi Produk Tenun Ikat Nusa Tenggara Timur Dengan Paduan Teknik Tenun dan Batik. Adapun motif nuntik yang dihasilkan berjumlah 7 motif yaitu; Jago, Gading, Gajah, Kapas, Lontar, Tumpal, dan Perhiasan (Salma, Syabana, Satria, \& Cristianto, 2018).

\section{Penerbitan Buku Dan Katalog}

Tahun 1973 BBKB ketika itu bernama Balai Penelitian Batik dan Kerajinan telah menerbitkan buku Seni Kerajinan Batik yang disusun oleh S. K. Sewan Susanto. Buku besar dan tebal dengan cetak hard cover, sangat eksklusif pada masanya. Buku ini kemudian menjadi rujukan utama bagi para mahasiswa yang mempelajari batik. Tampilan yang mantap, sebagai cerminan bobot keilmuan batik yang terkandung di dalamnya. Sentilan yang cukup memantik inovasi motif batik antara lain ketika membahas tentang desain motif batik Pekalongan waktu itu, penulisnya menyatakan bahwa batik Pekalongan dalam beberapa hal sudah baik dan mempunyai keunggulan-keunggulan, namun dalam segi seni motifnya masih perlu atau dapat diusahakan peningkatannya (Susanto, 2018) Langsung atau pun tidak langsung, dewasa ini dapat disaksikan peningkatan pesat beragamnya desain motif batik Pekalongan yang bermutu dan terserap pasar dengan baik. Pada tahun 1980, buku ini dicetak ulang dengan sedikit penyempurnaan. Pada tahun 2018 buku ini dicetak ulang lagi, dengan penambahan data mutakhir hasil litbang BBKB, termasuk hasil pengembangan motif yang telah dilakukan. Salah satu motif pengembangan yang 
dimuat adalah motif khas Bali yaitu Teratai Banji, dapat dilihat dalam Gambar 2.

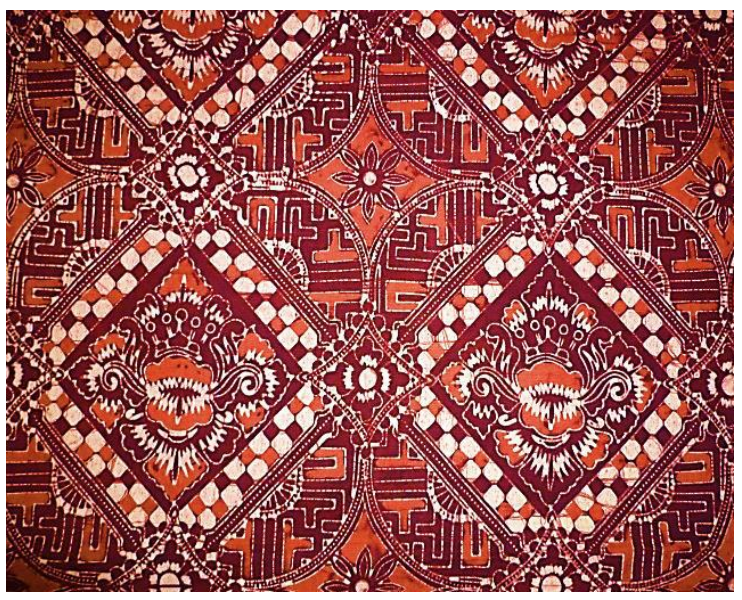

Gambar 2. Motif Teratai Banji khas Bali

(Salma, Masiswo, Satria, \& Wibowo, 2015)

Pada tahun 1981 BBKB melakukan kegiatan Pengumpulan Motif Batik Untuk Buku, yang berhasil menghimpun motifmotif tradisional batik Jawa sebanyak 176 jenis motif. Adapun jenis motifnya adalah; 33 motif jenis parang, 59 motif jenis ceplok, 84 motif jenis semen dan lainnya. Kumpulan motif ini dikumpulkan dan dijilid menjadi semacam katalog. Tahun berikutnya 1982, BBKB melakukan kegiatan yang sama dengan berhasil menghimpun 125 yang terdiri dari; 17 motif jenis parang, 22 motif jenis ceplok, dan motif 86 jenis semen serta jenis lainnya. Kumpulan motif ini juga dikumpulkan dan dijilid menjadi semacam katalog. Katalog dicetak dalam ukuran besar yaitu A2, sehingga desain motif langsung dapat disalin pada kain dan tidak perlu skala pembesaran gambar. Katalog ini beredar luas di Perguruan Tinggi Seni dan IKM-IKM batik dengan perbanyakan foto copy. Kumpulan desain yang ada dalam katalog tersebut dipakai oleh IKM untuk disalin langsung pada kain untuk dibatik, namun juga banyak dijadikan acuan untuk mengembangkan desain motif baru.

Pada tahun 1985 BBKB yang waktu itu bernama Balai Besar Penelitian dan Pengembangan Industri Kerajinan dan Batik menerbitkan buku hasil kompilasi dan evaluasi dari kedua katalog di atas (Pengumpulan Motif Batik untuk buku tahun 1981 dan 1982). Buku ini berisi teori jenis atau penggolongan motif, serta 170 gambar motif batik tradisional Jawa. Adapun jenis motifnya adalah; 31 motif jenis parang, 58 motif jenis ceplok, 81 moti jenis semen dan lainnya. Buku ini dicetak dalam ukuran A3. Buku ini beredar di Perguruan Tinggi Seni dan IKM batik dengan perbanyakan foto copy, namun kurang disukai karena bila ingin menerapkan motif yang ada, perlu dilakukan pembesaran motif batiknya. Buku ini juga banyak dijadikan acuan untuk mengembangkan desain motif baru.

Pada tahun 1997 BBKB menerbitkan Katalog Batik Indonesia yang berisi tentang; pengertian batik, proses pembuatan batik, teori motif batik, zat warna batik, tata warna batik, bahan kain batik, dan motif-motif batik tradisional dari berbagai daerah. Katalog berisi selain berisi motif-motif tradisional batik Jawa, juga memuat motif hasil penenembangan litbang BBKB tahun 1996 yaitu motif batik khas daerah Kalimantan Tengah. Tahun 2002 BBKB menerbitkan katalog lagi yaitu Katalog Beberapa Desain Etnik Indonesia, yang dilengkapi terjemahannya dalam bahasa Inggris. Katalog ini berisi klasifikasi atau penggolongan motif batik. Pada tahun 2011 BBKB menerbitkan buku dalam bahasa Inggris berjudul Handbook Indonesian Batik. Buku ini berisi teknik tahapan proses membatik dan motif-motif klasik dan motif 
pengembangan yang isinya hampir sama dengan katalog yang diterbitkan tahun 1997. Namun sebelumnya BBKB juga sudah menerbitkan katalog berbahasa Inggris juga dengan judul yang sama yaitu Handbook of Indonesian Batik, namun sayang tidak dicantumkan tahun terbitnya. Katalog ini berisi teknik penyiapan kain sebelum dibatik dan proses tradisional yaitu nglowong, nembok, medel, ngerok, mbironi, nyoga, dan nglorod.

Pada tahun 2012 BBKB juga menerbitkan Katalog Batik Indonesia yang berisi; pengertian batik, proses pembatikan, dan motif tradisional serta motif pengembangan dari berbagai daerah. Isinya hampir sama hanya ada penambahan motif tradisis dari daerah-daerah yang lain. Selain itu diterbitkan juga Katalog Lomba Desain Batik BBKB 2012 yang berisi 10 motif finalis dan 6 juaranya, beserta desain seluruh peserta dengan cetak berwarna. Desain yang diklaim hak milik BBKB adalah desain para pemenang/finalis. Kegiatan ini adalah salah satu upaya untuk mendorong kreativitas pelajar dan mahasiswa untuk menciptakan motif-motif batik kreasi baru serta memupuk rasa cinta generasi muda terhadap batik.

\section{Pelatihan Batik Daerah}

Pelatihan batik umumnya berisi materi teori dan praktik tentang teknis produksi batik. Namun bila instruktur yang ditugaskan memiliki kemampuan mengembangkan desain, maka pelatihan tersebut akan diisi dengan materi pengembangan desain motif khas daerah setempat. Hal ini merupakan keuntungan tersendiri karena akan mampu menumbuhkan kreativitas peserta dalam menciptakan motif batik khas daerah yang sesuai identitas alam dan budaya mereka. Sebagai contoh adalah pelatihan batik di
Kota Baturaja, Sumatera Selatan. Pada saat itu kota Baturaja belum memiliki motif batik khas daerah. Oleh karena itu perlu diciptakan desain motif batik khas daerah yang sumber inspirasinya digali dari kekayaan seni tradisional daerah setempat yaitu seni ukir. Tujuan penciptaan seni tersebut adalah untuk menghasilkan motif batik yang unik, kreatif dan inovatif yang mempunyai ciri khas kota Baturaja. Kegiatan ini menghasilkan 5 motif yaitu Bungo Nan Indah, Embun Nan Sejuk, Air Nan Segar, Kotak Nan Rancak, dan Ceplok Nan Elok (Salma, 2014).

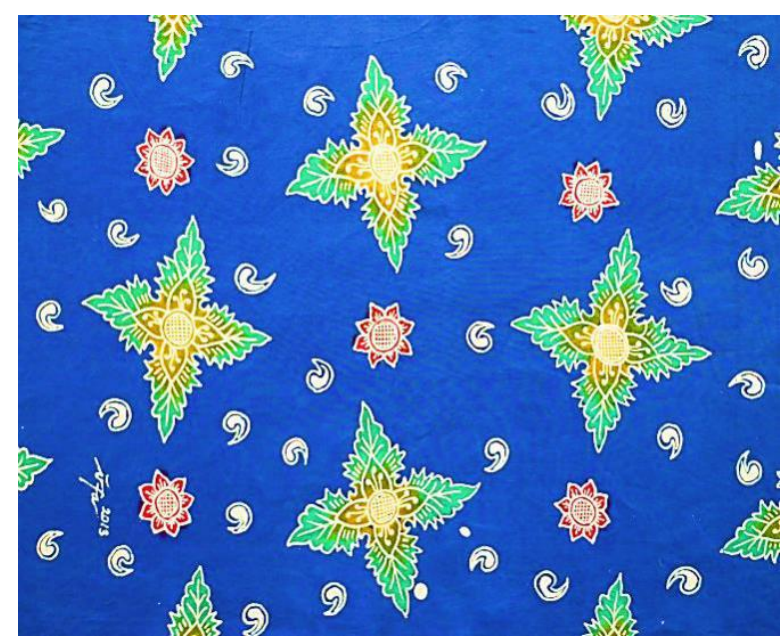

Gambar 3. Motif batik "Ceplok Nan Elok" khas Baturaja (Salma, 2014).

\section{Lomba Desain Motif Batik}

Pada tahun 1997, dibawah kepemimpinan Bapak Ir. Triwi Husodo, BBKB mengadakan. Lomba Desain Batik Untuk Busana, dengan juara 1 diraih oleh Edi Eskak, mahasiswa ISI Yogyakarta dengan judul karya "Motif Dayak Semarak". Tema lomba adalah pengembangan motif batik daerah. Lomba ini mengambil 3 juara utama dan 3 juara harapan, jadi total desain motif yang menjadi milik BBKB ada 6 motif baru (Eskak, 2000). 
Pada tahun 2012 ketika kepala BBKB dijabat oleh Drs. Freddy Silitonga, MM, BBKB kembali mengadakan Lomba Desain Batik Nasional dengan peserta khusus pelajar dan mahasiswa. Lomba ini bermaksud mendorong kreativitas pelajar dan mahasiswa untuk menciptakan motifmotif batik kreasi baru serta memupuk rasa cinta generasi muda terhadap batik. Adapun tujuan dari penyelenggaraan lomba ini, antara lain; Melestarikan dan mengembangkan seni budaya batik, Menggali ide kreativitas dan apresiasi generasi muda dalam merancang motif batik, Meningkatkan kecintaan dan kepedulian generasi muda terhadap pelestarian budaya batik, Menciptakan corak ragam batik baru bermotifkan kekhasan Nusantara sebagai jati diri batik Indonesia, dan Meningkatkan promosi batik. Ajang kreativitas dengan tema "Batik Nusantara" ini menghasilkan lima desain pemenang yaitu: Juara I "Nusa Merdu" karya Sirojul Munir, Juara II "Alas Nusantara" karya Yosep Arizal, Juara III karya Danti Rizki Amalia, Juara Harapan I "Gotong Royong" karya Irsam Aditya, dan Juara Harapan II "Warisan Langka" karya Agus Wahyu Permana. Karya finalis yang kuat nuansa batik daerahnya antara lain motif Angklung karya Niken Utami mahasiswi ISI Yogyakarta, seperti tampak dalam Gambar 4. Terpilihnya para pemenang tersebut tentunya karena karya desain telah memenuhi kreteria persyaratan panitia serta mempunyai nilai lebih dibanding peserta lainnya. Adapun kriteria penilaiannya adalah; Artistik, unik, orisinal; Kreativitas; serta Bisa diaplikasikan sebagai batik tulis dan cap. Lomba ini mengambil 10 finalis, dengan 3 juara utama, dan 3 juara harapan (Eskak, 2013).

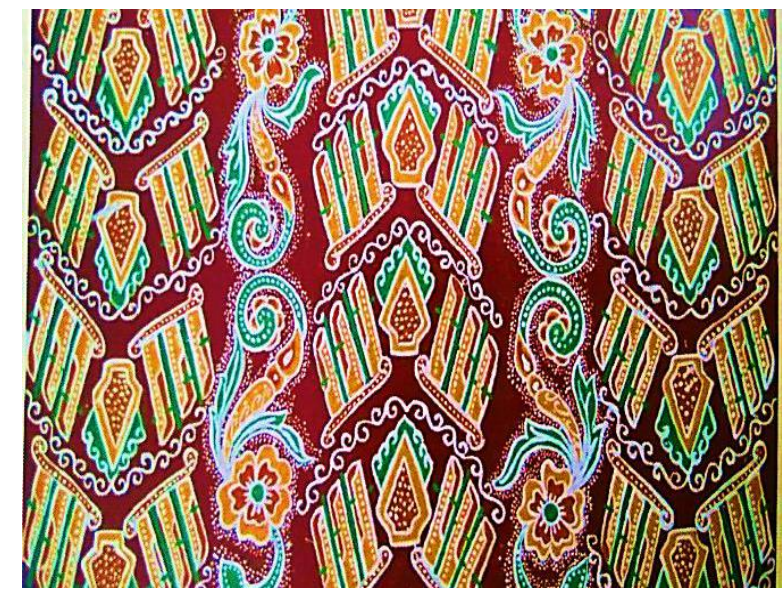

Gambar 4. Motif Angklung, karya Niken Utami (Sulistyono, Kartika, Kusumadhata, Saptono , Ekowati, Sarjono., Paramadharma, \& Retnawati, 2012).

\section{Kreativitas Mandiri Pegawai}

BBKB senantiasa mendukung pegawainya dalam mengembangkan geliat kreativitas penciptaan motif batik untuk masyarakat luas, baik formal kedinasan maupun secara mandiri. Adapun aktivitas secara mandiri didapatkan beberapa kegiatan. Pada tahun 2012 Disperindag Kabupaten Mojokerto mengadakan Lomba Desain Batik Khas Mojopahit dengan tema "Mengembangkan kreativitas seni budaya melalui lomba desain batik dalam rangka meningkatkan kekayaan motif batik Mojopahit" (Hino, 2012). Mojopahit sebagai kerajaan terbesar dalam sejarah Indonesia memiliki kekayaan seni dan budaya yang patut dilestarikan, termasuk seni motif batik yang dapat digali dan dikembangkan. Batik yang memiliki nilai ekonomi diharapkan dapat meningkatkan daya saingnya dengan penggunaan motif khas Mojopahit. Untuk tujuan tersebut serta melestarikan seni budaya Mojopahit, salah satu caranya adalah menggali motif desain batik khas 
Mojopahit. Edi Eskak pegawai BBKB mengikuti lomba secara mandiri dan meraih juara II dengan desain motif batik berjudul Surya Citra Majapahit (Salma, 2012). Karya desain motifnya dapat dilihat dalam Gambar 5. Hal ini juga merupakan sumbangsih BBKB dalam mengembangkan desain batik khas daerah Mojokerto.

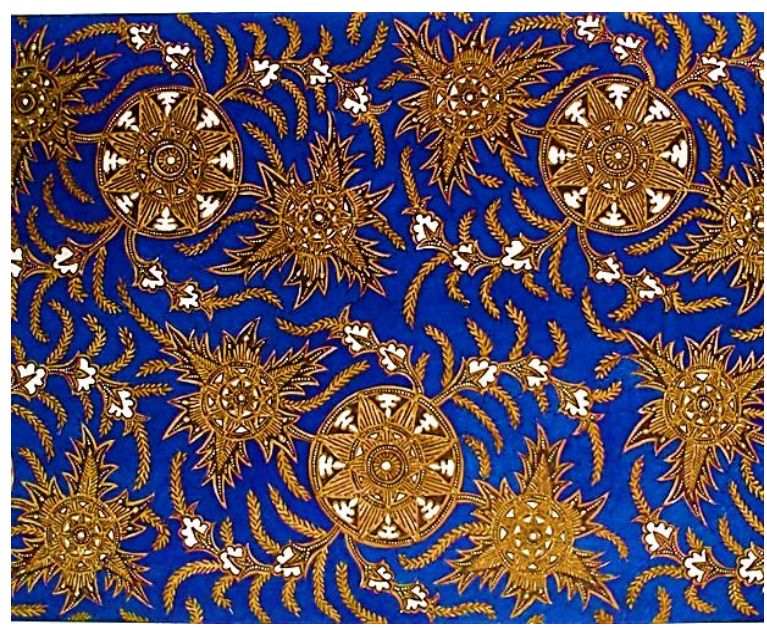

Gambar 5. Motif Surya Citra Majapahit (Salma, 2012)

Dekranasda Kabupaten Sleman berkerja sama dengan Disperindag Kabupaten Sleman dalam rangka melestarikan dan mengembangkan seni budaya batik, membangkitkan produktivitas IKM batik, serta mencari identitas batik khas Kabupaten Sleman mengadakan Lomba Desain Batik Sleman (LDBS) 2012 tingkat nasional untuk umum (Soebanto, 2012). Tema yang diangkat adalah "Kekayaan Alam dan Budaya Kabupaten Sleman Dalam Karya Motif Batik", dengan kriteria penilaian orisinalitas ide, kreativitas dan inovasi, kompisisi warna, serta komposisi motif. Irfa'ina Rohana Salma pegawai BBKB mengikuti lomba secara mandiri dan meraih juara II dan juara favorit dengan desain motif batik berjudul Semarak Salak (Salma \& Eskak, 2012). Hal ini juga merupakan sumbangsih BBKB dalam mengembangkan desain batik khas daerah Sleman, Daerah Istimewa Yogyakarta.

\section{Pengembangan Yang Belum Optimal}

Mencermati data yang ada menunjukkan bahwa pengembangan desain motif batik oleh BBKB menunjukkan performa yang setengah hati, sehingga menunjukkan hasil yang kurang optimal. Tabel 1 menunjukkan progres pengembangan yang telah dilakukan dari tahun 1973 sampai dengan tahun 2018 dengan hasil desain motif khas daerah hanya berjumlah 93 buah.

Buku pertama yang diterbitkan BBKB tahun 1973 karangan S.K. Sewan Susanto telah menyentil tentang pentingnya pengembangan motif batik, namun dalam lebih dari 4 dasawarsa hanya dihasilkan 93 buah desain pengembangan motif batik khas daerah. Model pengembangan yang dilakukan dengan melalui program kerja litbang tahunan kantor menghasilkan 70 motif. Penerbitan buku atau katalog merupakan pemuatan hasil litbang yang telah dilakukan jadi tidak menambah jumlah desain baru yang dihasilkan. Pelatihan batik daerah tidak signifikan dalam pengembangan jumlah motif, yang tercatat hanya 1 pelatihan yang menghasilkan penambahan 5 buah motif. Lomba desain motif batik di BBKB baru tercatat 2 kali menyumbang penambahan 16 motif, suatu jumlah yang teramat kecil dari yang seharusnya dapat dilakukan oleh lembaga 
litbang besar khusus kerajinan dan batik. $B B K B$ juga mendukung kreativitas mandiri yang dilakukan oleh pegawainya, tercatat ada 2 kegiatan yang telah dilakukan dan turut menambah 2 motif.

Tabel 1. Pengembangan batik motif khas daerah oleh BBKB (1973-2018)

\begin{tabular}{|c|c|c|c|}
\hline $\begin{array}{l}\text { Ta- } \\
\text { hun }\end{array}$ & Daerah & Model & $\begin{array}{c}\text { Jum- } \\
\text { lah }\end{array}$ \\
\hline 1973 & - & Buku & - \\
\hline 1980 & - & Buku & - \\
\hline 1981 & - & Katalog & - \\
\hline 1982 & - & Katalog & - \\
\hline 1985 & - & Buku & - \\
\hline 1996 & Kalteng & Litbang & 15 \\
\hline 1997 & - & Lomba desain & 6 \\
\hline 1997 & - & Katalog & - \\
\hline 2002 & - & Katalo & - \\
\hline 2004 & Sumut & Litbang & 12 \\
\hline 2011 & - & Buku & - \\
\hline 2012 & - & Katalog & - \\
\hline 2012 & Mojokerto & Mandiri & 1 \\
\hline 2012 & Sleman & Mandiri & 1 \\
\hline 2012 & - & Lomba Desain & 10 \\
\hline 2013 & Melayu & Litbang & 10 \\
\hline 2014 & Baturaja & Pelatihan & 5 \\
\hline 2014 & Maluku & Litbang & 3 \\
\hline
\end{tabular}

\begin{tabular}{rccc}
\hline 2015 & Bali & Litbang & 5 \\
2015 & Jember & Litbang & 6 \\
2016 & Kupang & Litbang & 6 \\
2017 & Papua & Litbang & 6 \\
2018 & NTT & Litbang & 7 \\
2018 & - & Buku & - \\
& & & 93 \\
\hline
\end{tabular}

\section{KESIMPULAN DAN SARAN \\ Kesimpulan}

Pengembangan batik motif khas daerah yang telah dilakukan oleh BBKB dari tahun 1973 sampai dengan tahun 2018 dari data yang tercatat menghasilkan 93 motif. Model pengembangan yang dilakukan yaitu; melalui program kerja litbang tahunan kantor, penerbitan buku dan katalog, pelatihan batik daerah, lomba desain motif batik, dan kreativitas mandiri pegawainya. Model program kerja litbang tahunan kantor menghasilkan 70 motif. Penerbitan buku dan katalog merupakan pemuatan hasil litbang yang telah dilakukan jadi tidak menambah jumlah desain baru yang dihasilkan. Pelatihan batik daerah menghasilkan penambahan 5 motif. Lomba desain motif batik di BBKB menyumbang penambahan 16 motif. Kegiatan kreativitas mandiri yang dilakukan oleh pegawainya, turut menambah 2 motif. Program yang paling efektif adalah pengembangan motif yang langsung dipraktikkan dalam suatu pelatihan batik daerah. Kegiatan-kegiatan tersebut walaupun belum maksimal telah menghasilkan batik yang memiliki ciri khas 
kedaerahan yang semakin menambah khasanah kekayaan corak batik Indonesia.

Saran

Perlu dipahami bersama, terutama oleh para pengambil kebijakan tentang pentingnya pengembangan industri batik daerah yang dibarengi dengan pengembangan desain motifnya yang diangkat dari ciri khas alam dan budaya setempat, sehingga menghasilkan motif khas daerah yang menarik dan berdaya jual. BBKB perlu lebih mengoptimalkan peran dalam pengembangan batik motif khas daerah. Karya-karya desain motif hasil pengembangan hendaknya didaftarkan kepemilikan Hak Cipta ataupun Desain Industri, sehingga hasil ciptaan terlindungi secara hukum.

\section{KONTRIBUSI PENULIS}

Penulis adalah sekaligus kontributor utama dalam penulisan Review: Pengembangan Batik Motif Khas Daerah Di Balai Besar Kerajinan Dan Batik ini.

\section{UCAPAN TERIMA KASIH}

Penulis mengucapkan terima kasih kepada Kepala dan staf BBKB atas layanan perpustakaan yang informatif, serta Bapak Edi Eskak S.Sn., M.Sn, (peneliti dan desainer) yang telah bersedia meluangkan waktu dan memberikan informasi yang berguna untuk tulisan ini.

\section{DAFTAR PUSTAKA}

Eskak, E. (2000). Pemanfaatan Kayu Limbah Industri Mebel Untuk Penciptaan Karya Seni. Institut Seni Indonesia Yogyakarta.

Eskak, E. (2013). Mendorong Kreativitas Dan Cinta Batik Pada Generasi Muda Kritik Seni Karya Pemenang Lomba Desain Batik Bbkb
2012. Dinamika Kerajinan Dan Batik, 30(1), $1-10$.

https://doi.org/http://dx.doi.org/10.22322/ dkb.v30i1

Eskak, E. (2018). Wawancara Pengembangan Desain Motif Batik, December 17, 2018. Yogyakarta.

Hino, R. (2012). Lomba Desain Batik Khas Mojopahit. Retrieved January 9, 2019, from https://suryamojopahit.wordpress.com/tag /mojopahit/

Ja'far, A. dan R. (1996). Penerapan Ragam Hias Kalimantan Tengah Untuk Motif Batik. Dinamika Kerajinan Dan Batik, 15, 39-45.

Masiswo dan Atika, V. (2014). Aplikasi Ornamen Khas Maluku Untuk Pengembangan Desain Motif Batik. Dinamika Kerajinan Dan Batik, $3(1), 22-30$.

Moleong, L. J. (2012). Metodologi Penelitian Kualitatif. Bandung: Remaja Rosdakarya.

Murwati, E. S. dan M. (2013). Rekayasa Pengembangan Desain Motif Batik Khas Melayu. Dinamika Kerajinan Dan Batik, 30(2), 67-72.

Nazir, M. (2013). Metode Penelitian. Bogor: Ghalia Indonesia.

Permenperin Nomor: 46/M-IND/PER/6/2006. Permenperin Nomor: 46/MIND/PER/6/2006 (2006). Indonesia. Retrieved from http://lib.kemenperin.go.id/neo/detail.php? id $=204795$

Riyanto, Pamungkas, A.W. \& Ja'far, M. A. (1997). Katalog Batik Indonesia. Yogyakarta: Balai BesarPenelitian dan Pengembangan Industri Kerajinan dan Batik.

Salma, I. R., \& Eskak, E. (2012). Kajian Estetika Desain Batik Khas Sleman Semarak Salak. Dinamika Kerajinan Dan Batik, 32(2), 1-8.

Salma, I. R., Eskak, E., dan Wibowo, A. A. (2016). Kreasi Batik Kupang. Dinamika Kerajinan Dan Batik, 33(1), 45-54.

Salma, I. R., Masiswo., Satria, Y., dan Wibowo, A. A. (2015). Pengembangan Motif Batik Khas Bali. Dinamika Kerajinan Dan Batik, 32(1), 23-30.

Salma, I. R., Ristiani, S., dan Wibowo, A. A. (2017). Piranti Tradisi Dalam Kreasi Batik Papua. Dinamika Kerajinan Dan Batik, 34(2), 63-72. 
Salma, I. R., Syabana, D. K., Satria, Y., dan Cristianto, R. (2018). Diversifikasi Produk Tenun Ikat Nusa Tenggara Timur Dengan Paduan Teknik Tenun Dan Teknik Batik. Dinamika Kerajinan Dan Batik, 35(2), 85-94.

Salma, I. R., Wibowo, A. A., \& Satria, Y. (2015). Kopi Dan Kakao Dalam Kreasi Motif Batik Khas Jember. Dinamika Kerajinan Dan Batik, 32(2), 63-72.

Salma, I. R. (2012). Kajian Estetika Desain Batik Khas Mojokerto "Surya Citra Majapahit." Ornamen, 9(2), 123-135.

Salma, I. R. (2014). Seni Ukir Tradisional Sebagai Sumber Inspirasi Penciptaan Batik Khas Baturaja. Dinamika Kerajinan Dan Batik, 31(2), 75-83. https://doi.org/http://dx.doi.org/10.22322/ dkb.v31i2.1070

Sartika, D., Eskak, E., dan Sunarya, I. K. (2017). Uma Lengge Dalam Kreasi Batik Bima. Dinamika Kerajinan Dan Batik, 34(2), 73-82.

Sejarah BBKB. (2018). Retrieved January 11, 2019, from

https://bbkb.kemenperin.go.id/page/show/ sejarah_0

SNI 0239. Batik - Pengertian dan Istilah (2014). Republik Indonesia: Badan Standardisasi Nasional.

Soebanto, H. (2012). Dekranasda Gelar Lomba Desain Batik Khas Sleman. Retrieved January 9, 2019, from https://jogja.antaranews.com/berita/29845 6/dekranasda-gelar-lomba-desain-batikkhas-sleman

Suhartini, T., Haryanto T., dan Widjanarko. (2004). Pemanfaatan Ragam Hias Etnik Sumatera Utara Untuk Pengembangan Motif Batik. Dinamika Kerajinan Dan Batik, 21, 16-22.

Sulistyono, D. (2012). Katalog Lomba Desain Batik Nasional Balai Besar Kerajian dan Batik 2012. Yogyakarta: Balai Besar Kerajinan dan Batik.

Susanto, S. K. S. (2018). Seni Kerajinan Batik Indonesia. (Tim Ahli BBKB, Ed.). Yogyakarta: ANDI.

Yoga, W. B. S., \& Eskak, E. (2015). Ukiran Bali Dalam Kreasi Gitar Elektrik. Dinamika Kerajinan Dan Batik, 32(2), 117-126. https://doi.org/http://dx.doi.org/10.22322/

dkb.v32i2.1367.g1156 
IKh Dinamika Kerajinan dan Batik: Majalah Ilmiah. Vol. 36 No. 2, Desember 2019, Hal. 149-162 